\title{
Portré Dr. Török Krisztináról a Nemzeti Egészségfejlesztési Intézet távozó főigazgatójáról
}

\author{
Portrait of Dr. Krisztina Török the former director general of National \\ Institute for Health Development
}

\author{
Szerző: Pári Mónika $\bowtie$ \\ Nemzeti Egészségfejlesztési Intézet
}

Beküldve: 2016.09.28.

Kulcsszavak: Nemzeti Egészségfejlesztési Intézet, egészségfejlesztés, Dr. Török Krisztina, népegészségügy

Keywords: National Institute for Health Development, health promotion, Dr. Krisztina Török, public health

\begin{abstract}
Miről szól egy portré? Az emberről magáról, vagy az intézményről, amit vezetett? Talán a kettő nem elválasztható. Egy olyan szakasz zárult most le a Nemzeti Egészségfejlesztési Intézet életében, ahol a személyiség változást hozott, nyomot hagyott az intézmény életében, melynek egy meghatározó szakasza Dr. Török Krisztina nevéhez fúződik.
\end{abstract}

A Főigazgató asszony azzal a misszióval jött intézetünkbe 2014-ben, hogy egy olyan egyedülálló népegészségügyi hálózatot építünk, egy olyan központi irányító intézménnyel, mely az Egészségfejlesztési Irodákat koordinálja, segíti módszertanokkal, disszeminál és kommunikál.

Az Országos Egészségfejlesztési Intézet (OEFI) előélete kellően terhelt volt, hogy mindez valódi kihívást jelentsen egy olyan ember számára, aki már két intézmény vezetője volt itteni kinevezése előtt. $A z$ OEFI tevékenysége nem kis részben összefonódott a magyarországi népegészségügy megítélésével, támogatottságával. Az intézet egyik kiemelkedő szakmai és szervezeti időszaka dr. Vokó Zoltán vezetése alatt volt. Krisztina korábbi együttműködéseik során, és azóta is mindig nagyra tartotta őt, mint embert, szakmailag pedig kétség sem férhet a zsenialitásához. Amikor ő vezette az intézményt tudott egy olyan szakmai célt adni a kollégáknak, ami valódi csapatszellemet kovácsolt, sikerült uniós pályázati források felhasználásával jövőképet adni az OEFInek. Az ő távozása után ezt a szakmai fellendülést nem táplálta tovább újabb irányvonalak kijelölése, hanyatlásnak indult az intézmény hírneve is. Ebben az időpillanatban belépni egy intézmény élére menedzsment szemlélettel az erősen szakmavezérelt környezetbe, kihívás volt.

„Amit a legnagyobb fájdalomként élek meg, hogy a projektek sikeres lezárása után nem volt lehetőségem a korábbi TÁMOP-os projekteken dolgozóknak, főként a fiataloknak, akik korábban egy célállomásnak tekintették az OEFI-t, munkát és lehetőséget adni. Aki népegészségügyi projekteken dolgozott, mindenki ide akart jönni. Borzasztó csalódás volt azt megélni, hogy nem tudtuk felvenni ôket. Az intézetben dolgozóknak pedig forráshiány okán nem tudtunk szakmai elköteleződést, innovatív irányokat, kihívást adni."

Ha arról kérdezem Főigazgató asszonyt, hogy mi volt mégis mindezek ellenére a legjobb az itt töltött időben nem gondolkodik túl sokat a válaszon:

„Vannak személyes és intézményi pozitívumok is. Sikernek élem meg, hogy a szakma újra kedvezően 
nyilatkozik a NEFI-ről, hogy az intézet újra jó irányban halad. Legfontosabbnak mégis azt tartom, amikor iskolák írnak személyes levelekben, civil szervezetek vagy éppen az Országos Mentőszolgálat csatlakozik a Fuss magadért egy kört kampányhoz, amikor települések jelzik, hogy országos szervezettség nélkül is megtartják a Mozgás Éjszakáját (több tízezreket megmozgató országos kampány 2014-ben és 2015-ben. a Szerk.), mert fontosnak gondolják a programot. Ezért lenne lényeges megérteni a szakértő kollégáknak, hogy ez is a munkánk lényege, ez az intézetünk valódi küldetése: hogy szemléletet formáljunk. Ha csak 100 embernél sikerült valamit elérnünk idén, akkor jövőre majd többen lesznek, hogy a valódi változások eléréséhez nem csupán a kutatások szükségesek, hanem, hogy elmenjünk az emberek közé, hogy megérezzük, a bőrünkön megtapasztaljuk, hogy lássuk, hogy hány ember lesz boldogabb, egészségesebb és aktívabb egyénileg és közösségben a munkánk eredményeként. Ez ad inspirációt, ez ad pozitív motivációt, erre lehet büszke valójában egy szakember."

„Személyes életemben pedig valódi változást hozott ez az inspiráló környezet. Én élsportoló voltam, de megadtam magamnak a kifogáskeresés luxusát, hogy úgysincs időm a sportra. De az intézet nagyon megtanított rá, hogy minél tovább húzom ezt, annál nehezebb elérni, hogy tényleg jól érezzem magam a bőrömben. Ezzel együtt rájöttem mekkora felelőssége van ebben az embernek, az egyénnek. Azóta futok, odafigyelek az étkezésemre és a megfelelő pihenésre."

Az intézmény életében is hasonlóan inspiratív változások tették, teszik élhetőbbé a környezetet. Múködik a „Boszorkánykonyha”, ahol dietetikus vezetésével a kollégák egészséges, könnyen elkészíthető ételekkel ismerkedhetnek, van film-klub, és csikung elemekkel tarkított reggeli torna kétszer egy héten, valamint, a lehetőségekhez mérten rendszeres, szervezett kirándulások. Mindezen túl, Krisztina továbbra is kitart amellett, hogy bár a felsorolt események közösségépítőek, hasznosak a testi-lelki egészségünk szempontjából, de munkahelyi, szakmai csapatot csak a közös a munka tud igazán kovácsolni. A fentiekből már láthatunk egy képet Dr. Török Krisztina vezetői attitűdjéről, emberközpontúságáról, elköteleződéséről. Mégis, ami a NEFI életében valódi újítást jelentett személyében, az a menedzsment szemlélet. Népszerú védekezési taktika a közigazgatásban, hogy pénzhiány miatt nem lehet ezt a fajta vezetési stílust maradéktalanul meghonosítani egy közintézményben. Krisztina ezzel sosem értett egyet. Valóban a három legnagyobb kihívás ilyen környezetben a pénzhiány, a menedzsment eszközök hiánya (motivációs eszközök), HR frissítés, és ezek következményeként: a szervezet-átalakítás lehetősége. A menedzsment szemlélettel, amit hozott, amit a közigazgatásban ugyanúgy lehet alkalmazni, arra próbálta érzékenyíteni a kollégákat, hogy szükséges eredményorientáltan gondolkodni, innovatívan cselekedni, kezdeményezőnek lenni.

„Rossz volt, hogy egy ostornak éreztem magam, főleg, hogy védekezésképpen próbálták a szakmát elhatárolni a menedzsmenttől, de valójában nem szabad különválasztani e két dolgot: egy menedzsernek az a dolga, hogy jól koordinálja a szakmát. Megtanítsa a kollégákat a változásra való készségre. Remélem ez részben sikerült."

„Hogy milyen érzéssel távozom? Úgy érzem az intézetből sokan úgy élték meg, mint egy újabb vezető távozását, mint egy újabb állomást, ahonnan úgyis tovább megyünk. A magam részéről úgy érzem számos konfliktust nem tudtam feloldani. A szeniorok közötti tudományos konfliktusokat nem sikerült elrendezni, ez talán nem is az én dolgom lett volna, de mindenesetre segítette volna a közös munkát, ha ebben sikerül kompromisszumot kötni. Mégis úgy gondolom, hogy egy olyan csapatot ismertem meg, akik erkölcsileg nagyon magasan állnak, ugyanakkor elfáradtak. Elfáradtak abban, amiben én is talán: a nem támogató környezetben, a folyamatos bizonytalanságban alkotni.

Mégis, ha üzenhetnék, vagy tanácsolhatnék valamit nekik, az mindenképpen az lenne, hogy tanulják, szokják meg a változáshoz való alkalmazkodást, a toleranciát, az egymás véleményének elfogadását, az emberközpontúságot a tudományközpontúság mellett. Mert megvalósulni az a módszertan tud, ami figyelembe veszi a környezetet, ahová adaptálni kívánjuk, ami figyelembe veszi a befogadó készséget és figyeli a reakciókat. A változás mindig alulról jön, mindig kicsiben indul el. Meg kell tanulni örülni a legapróbb sikereknek is. Ezen a területen dolgozni, sosem gyors sikertörténet. Meg kell találni szemé- 
lyesen azt a spirituszt, azt a pluszt, ami mindenkiben benne van. Ezt keressék, ha hosszútávon élvezni akarják, amit csinálnak, annak ez a záloga."

Jelenleg nem tudjuk, nem látjuk, hogy a változó intézményi és politikai környezetben a NEFI-nek, vagy akár a népegészségügynek hol és milyen szerepe lesz. Az viszont kétségtelen, hogy Dr. Török Krisztina vezetésével tanulóképesebbé, nyitottabbá és innovatívabbá váltunk. Intézményi szinten és talán többek esetében személyesen is. Addig is: várjuk a változást, amihez már reméljük, jobban tudunk alkalmazkodni. 